\title{
Standard Multimodal Postoperative Analgesia Might Not Be Equally Effective When Comparing Anterior and Posterior Spondylodesis
}

1 Josipa Dovranić

1 Matija Bagarić

1 Marija Karača

2 Vladimir Trkulja

${ }^{1}$ Danijel Matek

1 Department of Orthopaedics, University Hospital Center Zagreb, University School of Medicine, Zagreb, Croatia

2 Department of Pharmacology, Zagreb University School of Medicine, Croatia

Article received: 11.02 .2020 .

Article accepted: 08.04.2020.

DOI: $10.24141 / 2 / 4 / 1 / 7$

Author for correspondence:

Josipa Dovranić

Salata 6, 10000 Zagreb, Croatia

E-mail: josipa_dovranic@hotmail.com

Danijel Matek

Salata 6, 10000 Zagreb, Croatia

E-mail: dmatek@gmail.com

Keywords: scoliosis, spondylodesis, pain management, analgesics

\section{Abstract}

Introduction. Surgical treatment of structural adolescent scoliosis, either through anterior or posterior spinal fusion, results in severe pain.
Aim. In comparison with the anterior approach, the posterior approach is considered advantageous in that several spine curvatures can be corrected in a single operative act. The aim was to compare the effectiveness of a morphine-based multimodal protocol over the first 48 postoperative hours in anterior and posterior surgeries.

Methods. This retrospective chart review included consecutive adolescents (10-21 years of age) treated using either the anterior $(n=28)$ or the posterior $(n=30)$ approach at a single hospital centre over 3 years (2015-2017). Intravenous morphine (48 mg/24 hours) was administered at hourly intervals; pain was assessed using an 11-point (higher score=worse pain) visual analogue scale on 12 occasions during the first 24 hours and on 3 occasions during the second 24 hours. Additional analgesia (non-opioid or weak opioid) was delivered on demand and/or according to medical assessment.

Results. With adjustments for age and number of affected spinal segments, VAS pain scores were lower in the anterior approach, overall (48 hours) (difference $=-18 \%, 95 \% \mathrm{Cl}-30$ to -5$)$, and particularly over hours $0-3(-23 \%, 95 \% \mathrm{Cl}-36$ to $-7 \%)$ and hours $4-6$ $(-26 \%, 95 \% \mathrm{Cl}-40$ to $-10 \%)$ after the surgery. The rate of additional analgesic administrations was comparable throughout the observed period (rate ratios around 1.0).

Conclusion. The evaluated intravenous morphinebased multimodal analgesic protocol appeared less effective in surgeries using the posterior approach, suggesting that the two approaches might require different protocols for the same level of analgesia. 


\section{Introduction}

Structural scoliosis is a three-dimensional spine distortion comprised of frontal (sideways), horizontal (rotation and torsion) and sagittal (kyphosis or lordosis) components (1). Etiologically, it is classified as idiopathic (70-80\% of all cases) or secondary, i.e., neuromuscular, due to congenital disorders of connective tissue (Marfan syndrome) or other causes (rheumatic diseases, trauma, tumours, infections, contractures, metabolic disorders) (2). The main feature of structural scoliosis is the rotational component and the occurrence of the rib hump $(1,2)$. According to the localization and the curvature direction, it is classified as cervical, thoracic, thoracolumbar or lumbar $(1,2)$. Thoracic and lumbar segments are the most commonly affected segments. The primary curvature also produces compensatory secondary curvatures to achieve the balance of the body and the spine (3). Idiopathic scolioses most commonly develop during the growth spurt of puberty and early adolescence, more often in girls than in boys (4).

Treatment procedures vary depending on the type of scoliosis. Initially, conservative methods are used, most commonly physical therapy and applying corrective devices, orthoses (5), worn $23,18,16$ or 12 hours/day depending on the curvature size, the age of the patient and the level of progression. Conservative treatment, however, is frequently not successful and in advanced cases surgical treatment is needed: spinal fusion (spondylodesis) in the corrected position is performed, either using the anterior or the posterior approach (6). Since the introduction by Hibbs in 1911 (7), a variety of surgical methods have been described, but only a few are still in use. In 1983, King et al. (8) proposed a concept of limited fusion for the main thoracic curvatures. Since then, the most commonly used surgical approaches have been the anterior approach (ventral derotational spondylodesis, VDS) and the posterior approach (transpedicular spondylodesis, Neurofrance ${ }^{\circledast}$ instrumentation). For the correction of curvatures, special instrumentation is used in order to correct and block ("stiffen") the selected segments (9). Studies indicate advantages of the posterior approach in that several curvatures can be corrected in a single operative act, as well as better functional outcomes and shorter hospital stay (10). However, both procedures are extensive, performed with gen- eral anaesthesia with intraoperative monitoring, large soft tissue incisions (skin, muscles, ligaments) and bone procedures, and always cause severe pain. Consequently, perioperative pain management is of great importance and potent regimens are required. Intravenous patient-controlled opioid analgesia (PCA) has been generally accepted as a basis for successful pain control in adolescents with idiopathic scoliosis (AIS) and has been compared to various other protocols such as epidural analgesia or intrathecal opioids (11). Different multimodal PCA-based protocols (e.g. with additional ketamine infusion, continuous wound in filtrations, intravenous lidocaine) (12) have also been evaluated in order to assess the potential of reducing opioid utilization and the adverse effects of opioids. Multimodal PCA (opioid)-based protocols including non-opioid and weak opioid analgesics have been rather commonly employed in this setting. One such protocol has been a standard procedure at our institution and has been employed in AIS patients regardless of whether they are treated using the anterior or the posterior approach. This analysis aimed to assess the relative efficiency of the protocol in the anterior and the posterior approach.

\section{Methods}

\section{Design and ethics}

This retrospective chart review included consecutive adolescents (age $\geq 10$ and $\leq 21$ ) with verified idiopathic scoliosis treated surgically using ventral derotational spondylodesis (anterior approach) or transpedicular spondylodesis (Neurofrance ${ }^{\circledR}$ instrumentation) (posterior approach) at the Department of orthopaedic surgery of the University Hospital Centre Zagreb over a period of three years (20152017). The analysis refers to data routinely collected through a standardized procedure approved by the Institutional Ethics Committee.

\section{Patient management and evaluation}

All surgeries were performed by two experienced surgeons, and the choice of the approach was at 
their discretion. Diagnostic procedures and criteria, indication for surgical treatment and the treatment itself were all in line with the national guidelines.

Upon transfer to the intensive care unit (ICU), morphine-based analgesia was administered by a nurse upon receiving a patient's request through the PCA system over 48 post-surgical hours as outlined in Figure 1: a) total daily (24 hours) dose of intravenous morphine was limited to a maximum of $48 \mathrm{mg}$; b) during the first 24 hours, all patients received two bolus doses of $4 \mathrm{mg}$ each, one hour apart (starting immediately upon ICU admission), followed by two $2 \mathrm{mg}$ doses an hour apart (i.e. a total of $12 \mathrm{mg}$ were delivered over the first 4 hours); c) the remaining $36 \mathrm{mg}$ were delivered in 18 administrations, each one hour apart; d) during the second 24 hours, $2 \mathrm{mg}$ were delivered in hourly intervals; e) pain severity was continuously assessed using an 11-point visual analogue scale (VAS), where $0=$ no pain and $10=$ excruciating pain, at time " 0 " (upon ICU admission) and then 1, 2, 3, 4, 6, 8, 12, $16,20,24,32,40$ and 48 hours later; $f$ ) on the basis of patient demand and clinical assessment (VAS score, previous administrations), additional analgesia was provided via intravenous non-opioid [paracetamol, ketoprofen or metamizole (dipyrone) sodium] or weak opioid analgesics (pethidine, tramadol).

\section{Measures of analgesic efficiency}

To quantify the level of analgesia, we evaluated: a) VAS pain scores across all assessment time-points over 48 hours, as well as averaged scores across assessment points (averages for assessments at 0-3 hours, 4-6, 8-16, 20-24, 32-48 hours after surgery); b) number of administrations of additional analgesics during the observed period and across post-surgical time-intervals $(0-4,>4-8,>8-16,>16-24$ and $>24-$ 48 hours after surgery); c) the proportion of patients receiving at least one dose of an additional analgesics during the observed period and also across postsurgical time intervals $(0-4,>4-8,>8-16,>16-24$ and >24-48 hours).

\section{Data analysis and effect measures}

We defined two primary and two secondary analyses for the comparison of the efficiency of the protocol in two surgical settings. Primary analyses: a) a general linear mixed model (surgery type, time, surgery ${ }^{\star}$ time interaction, with adjustment for age and the number of spine segments affected) was fitted to In-trans- formed VAS scores obtained at all 15 assessments. The difference between the anterior and the posterior approach was estimated (i) overall (the entire 48-hour period); and (ii) based on averaged scores (averages of assessment at 0-3, 4-6, 8-16, 20-24, 32-48 hours). No adjustment for multiple comparisons was employed, but potential differences in averaged scores were considered statistically significant only if the overall difference between the procedures was statistically significant. Differences are expressed as geometric means ratios (GMRs); b) a generalized linear mixed model with a log link and a Poisson distribution (surgery type, time, surgery*time interaction, adjustment for age and the number of spine segments) was fitted to the number of additional analgesic applications per patient per time interval $(0-4,>4-8,>8-16,>16-24$ and $>24-48$ hours after surgery). The difference between the anterior and the posterior approach was estimated (i) overall; and (ii) by time-interval. No adjustment for multiple comparisons was employed, but potential differences between the two approaches at individual time intervals were considered statistically significant only if the overall difference was statistically significant. Differences are expressed as rate ratios (RR; anterior/ posterior approach). Secondary analyses: a) area under the VAS score-time curve was determined (trapezoidal rule) for the entire observed period $\left(A \cup C_{0-48}\right)$, and also partial AUCs were determined for periods 0-4, 4-8, 8-16, 16-24 and 24-48 hours. A separate general linear model (type of surgery, age and number of affected spine segments) was fitted to each In-transformed AUC (total and partial). Potential differences between the anterior and the posterior approach in partial AUCs were considered statistically significant only if the difference in total AUC was significant; b) A generalized linear mixed model with logit link and binary distribution (surgery type, time, surgery*time interaction, age and number of affected spinal segments) was fitted to the proportion of patients requiring at least one additional analgesic administration (at time intervals of $0-4,>4-8$, > 8$16,>16-24$ and $>24-48$ hours after surgery). The difference between the anterior and the posterior approach was estimated (i) overall; and (ii) by timeinterval. No adjustment for multiple comparisons was employed, but potential differences between the two approaches at individual time intervals were considered statistically significant only if the overall difference was statistically significant. Differences are expressed as odds ratios (OR; anterior/posterior 
approach). For sensitivity analyses, all models were re-fitted so that the adjustment for the number of affected segments was replaced by the severity of scoliosis in the thoracic and the lumbar part (Cobb's angle) before or after the surgery. We used SAS 9.4 for Windows software (SAS Inc., Cary, NC, USA).

\section{Sample size considerations}

No formal sample size calculations were performed. We expected that the two surgery type groups would differ in size but expected that at least 20 subjects would be included in each group. We considered this to be a sufficiently large sample for (potential) detection of a difference with potential clinical relevance, based on the following reasoning: $A$. regarding VAS scores, a) the analgesic protocol is employed to keep pain at a sustainable level that could be defined as 2.5 score points (overall average for the observed period); b) a difference of $20 \%$ (or 0.5 score points) for the overall period could be considered practically relevant; c) with 15 repeated assessments, no subject attrition, with standard deviation of the difference at each assessment that is equal to the difference (100\% relative standard deviation), with autocorrelation of $0.5,20$ and 20 subjects in each group would enable $>90 \%$ probability to detect and overall difference in VAS scores of $20 \%$ at two-sided alpha $=0.05$; B. regarding additional analgesic administration, a) based on experience, we expected that during the 5 time intervals, on average, 1 additional analgesic administration would be delivered per patient: b) with the same assumptions as for the VAS scores (relative standard deviation of the difference $=100 \%$ ) and with 5 repeated assessments, the sample of 20 and 20 patients would attain $>90$ probability to detect a $20 \%$ overall difference at two-sided alpha $=0.05$.

\section{Results}

Overall, 58 adolescents were included, 28 treated using the anterior approach (only one boy) and 30 (7 boys) treated using the posterior approach (Table 1 ). Subjects in the former group had generally somewhat less severe scoliosis as judged by the pre-surgical Cobb angles, fewer segments were affected by spon- dylodesis, and the changes in Cobb angles resulting from the surgery where somewhat smaller (Table 1). Intrasurgical autotransfusion was used only with the posterior approach, and more patients required packed red cell transfusions (Table 1 ) indicating more extensive procedures when compared to the anterior approach, although without statistical significance. There were also slight differences in the length of the ICU stay and overall hospitalization (Table 1).

In the primary analysis, with adjustments for age and the number of affected segments, VAS scores for pain over time were consistently lower with the anterior approach than with the posterior approach (Figure 2). Overall, the scores were by around $18 \%$ (5\% to 30\%) lower (Figure 2). They were also lower at assessments taken at 0 to 3 hours (by 23\%), 4 to 6 hours (by 26\%) and 32 to 48 hours (by 36\%) (Figure 2). At the same time (and with the same adjustments), the number of additional analgesic applications appeared comparable between the groups (Figure 2). Sensitivity analyses (adjustments for Cobb angles instead of the number of affected segments) yielded closely similar estimates (not shown).

In the secondary analysis (Table 2), AUC $_{0-48}$ for VAS pain scores (the same adjustments as in the primary analysis) was by $26 \%$ (1\% to $45 \%$ ) lower with the anterior approach than with the posterior approach (GMR $=0.74$; 95\% Cl 0.55-0.99) (Table 2). At the same time (and with the same adjustments), the estimated probability of being administered at least one additional dose of analgesics for the entire 48-hour and across all time-intervals was comparable between the groups (Table 2).

AUCs were analysed by fitting general linear models to In-transformed values, and the proportions of patients being administered additional analgesics by fitting generalized linear mixed models with logit link and binary distribution. Adjustments were made for time, treatment ${ }^{\star}$ time interaction, age and number of affected spine segments.

\section{Discussion/ Conclusion}

Operative treatment of adolescent structural scoliosis is an example of a surgical procedure that is demanding for both the patient and the whole medical team 


\begin{tabular}{|c|c|c|c|c|}
\hline & Anterior & Posterior & D $(95 \% \mathrm{Cl})^{1}$ & $\boldsymbol{p}$ \\
\hline $\mathbf{N}$ & 28 & 30 & -- & -- \\
\hline Age (years) & $15(12-20)$ & $15(10-18)$ & $0(-1$ to 1$)$ & 0.884 \\
\hline Boys & $1(3.6)$ & $7(23.3)$ & $-19.7(-38.2$ to -2.2$)$ & 0.029 \\
\hline Pre-surgical Cobb angle, thoracic (degrees) & $58.5(5-97)$ & $61.5(35-93)$ & $-3(-10$ to 2$)$ & 0.219 \\
\hline Pre-surgical Cobb angle, lumbar (degrees) & $38(0-70)$ & $42(0-70)$ & $-8(-20$ to 0$)$ & 0.072 \\
\hline Number of affected spine segments & $7(5-11)$ & $9(5-12)$ & $-3(-4$ to -2$)$ & $<0.001$ \\
\hline Post-surgical Cobb angle, thoracic (degrees) & $15(0-43)$ & $13(3-36)$ & $2(-3$ to 6$)$ & 0.503 \\
\hline Change in Cobb angle, thoracic (degrees) & $-41(-75,13)$ & $-49(-75,30)$ & $4(-2$ to 11$)$ & 0.170 \\
\hline Post-surgical Cobb angle, lumbar (degrees) & $10(0-33)$ & $8(0-50)$ & $2(0$ to 10$)$ & 0.193 \\
\hline Change in Cobb angle, lumber (degrees) & $-18(-60,10)$ & $-33(-58,20)$ & 14 (3 to 25$)$ & 0.011 \\
\hline Peri-operative blood loss (mL)(x103) & $1.24(0.40-3.00)$ & $1.00(0.30-3.00)$ & $0.08(-0.22$ to 0.35$)$ & 0.602 \\
\hline Intrasurgical autotransfusion (mL) & Not used & $321(0-1250)$ & --- & --- \\
\hline Patients receiving packed red cells & $2(7.1)$ & $11(36.6)$ & $-29.5(-49.0$ to -8.7$)$ & 0.006 \\
\hline Intensive care unit stay (days) & $6(3-7)$ & $4(2-5)$ & 1 (1 to 2$)$ & $<0.001$ \\
\hline Hospitalization length (days) & 15 (10-19) & $15(11-42)$ & $-2(-4$ to 0$)$ & 0.028 \\
\hline
\end{tabular}

responsible. Early post-operative pain management is particularly challenging. Opioid-based (intravenous) patient-controlled analgesia (PCA) is considered a method most likely to yield satisfying results compared to alternatives like intrathecal opioid administration or continuous thoracic epidural analgesia (11).

Different multi-modal protocols based on opioid PCA have been assessed in order to reduce the risk of opioid side-effects (i.e. for the "opioid-sparing" effect). At our institution we use 48-hour multimodal protocol consisted of: a) intravenous opioid PCA with pre-defined bolus doses and their timing; b) pre-defined rules (amount, time-intervals) for maintenance doses; c) additional use of weak opioids or non-opi- oids intravenously, but with a constraint in individual doses as well as their frequency; d) continuous pain assessment at defined intervals. It has been routinely administered to idiopathic scoliosis patients. However, surgeries employing the anterior and the posterior approach differ in that the latter type is typically used in more extensive procedures (13), which was the case in the present analysis. Therefore, it was assumed that, as such, the protocol might not be equally efficient in both procedures. With the limitations inherent to an observational setting and a limited sample size, the present analysis indicates that analgesia achieved in patients treated by the posterior approach was less successful, primarily dur-

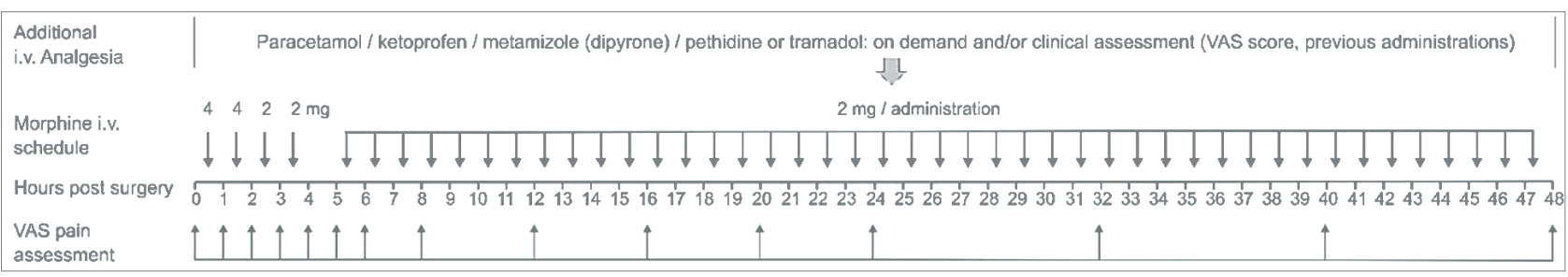

Figure 1. Outline of the intravenous (IV) morphine-based analgesic protocol employed and analgesiarelated procedures conducted during the first post-surgical 48 hours (undertaken at the intensive care unit, ICU). VAS - visual analogue scale 


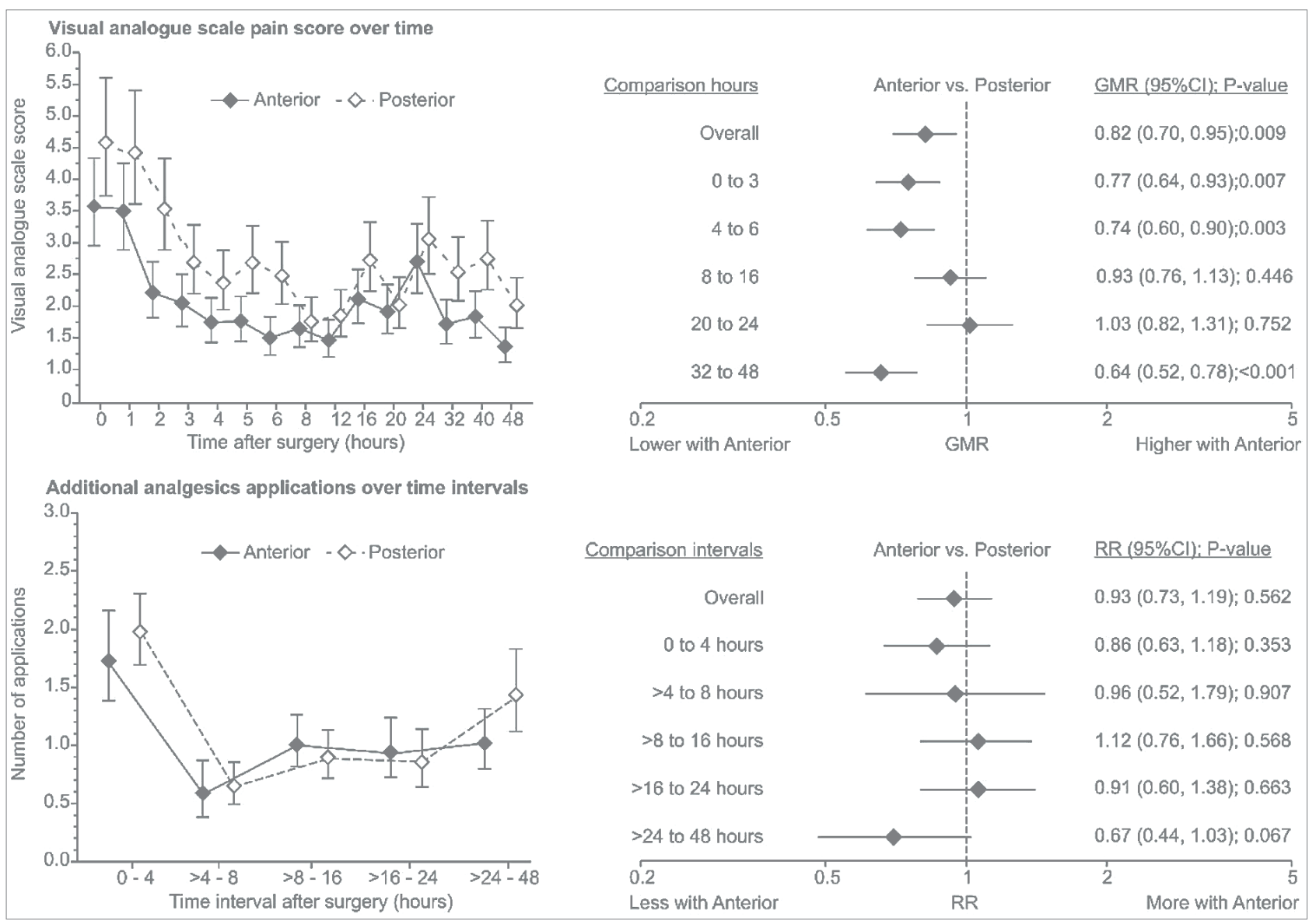

Figure 2. Development of Visual analogue scale (VAS) scores for pain over post-surgical time-points of assessment and differences between the anterior and the posterior approach across averaged time-points (upper panel) and development of number of additional analgesic applications over time intervals and differences between the anterior and the posterior approach (lower panel). Upper panel. Ln-transformed VAS scores were analysed in a general linear mixed model with treatment, time, treatment*time interaction, and with adjustments for age and the number of affected spine segments. Values are adjusted geometric mean scores with $95 \%$ confidence intervals $(95 \% \mathrm{Cl})$, and differences are expressed as geometric means ratios (GMRs) with 95\% Cl. Lower panel. The number of applications per patient per time interval was analysed in a generalized linear mixed model with a log link and Poisson distribution with the same effects as above. Values are adjusted geometric mean numbers of applications with $95 \% \mathrm{Cl}$ and differences are expressed as rate ratios (RR) with $95 \% \mathrm{Cl}$. The treatment*time interaction was insignificant in both models.

ing the first 6 hours after surgery - the period of the most intense pain. Based on the VAS pain scores that were evaluated hourly during this period, the difference was estimated as $20-25 \%$ weaker analgesia under the same morphine protocol and with a comparable utilization of additional analgesics (number of administrations, proportion of patients requiring it). We assumed that a $20-25 \%$ difference in intensity of analgesia could be practically relevant, but the present data do not indicate direct clues to support such an assumption. Indirectly, it does not seem to have had practically relevant consequences, at least considering the fact that the ICU stay was somewhat shorter in the group in which the posterior approach was used. In an additional analysis, the number of ICU days was analysed by quantile regression - with adjustments for age, number of segments and surgical approach, and there was no association between partial VAS AUC ${ }_{0-4}$ and the length of the ICU stay (not shown). In part, this could be due to the fact that, 
Table 2. Summary of secondary outcome analysis: Visual analogue scale scores (VAS) integrated as the area under the curve (AUC), overall and by factions, and odds of at least one administration of additional analgesics overall and by time intervals. Values are adjusted geometric means (AUC) or adjusted probabilities of events. Differences are expressed as geometric means ratios (GMR) or as odds ratios (OR) with $95 \%$ confidence interval (CI).

\begin{tabular}{|c|c|c|c|c|}
\hline \multirow[b]{2}{*}{ VAS AUC (points*time) } & \multirow[t]{2}{*}{ Anterior } & \multirow[t]{2}{*}{ Posterior } & \multicolumn{2}{|c|}{$\begin{array}{c}\text { Difference } \\
\text { Anterior vs. Posterior }\end{array}$} \\
\hline & & & GMR (95\% (Cl) & $p$-value \\
\hline Overall (0-48 hours) & 62.1 & 84.1 & $0.74(0.55-0.99)$ & 0.047 \\
\hline Fraction $0-4$ hours & 7.95 & 11.4 & $0.70(0.49-1.00)$ & 0.050 \\
\hline Fraction 4-8 hours & 4.43 & 6.33 & $0.70(0.46-1.07)$ & 0.098 \\
\hline Fraction $8-16$ hours & 8.49 & 8.63 & $0.98(0.56-1.73)$ & 0.956 \\
\hline Fraction $16-24$ hours & 12.2 & 13.2 & $0.92(0.59-1.46)$ & 0.729 \\
\hline Fraction $24-48$ hours & 25.6 & 40.6 & $0.63(0.35-1.12)$ & 0.116 \\
\hline Probability of at least one application (\%) & & & OR $(95 \% \mathrm{Cl})$ & $p$-value \\
\hline Overall over 48 hours & 34.5 & 36.7 & $0.90(0.60-1.37)$ & 0.633 \\
\hline Between 0 and 4 hours & 42.8 & 49.9 & $0.75(0.42-1.35)$ & 0.342 \\
\hline Between $>4$ and 8 hours & 20.7 & 20.3 & $1.03(0.47-2.26)$ & 0.947 \\
\hline Between > 8 and 16 hours & 34.5 & 29.8 & $1.24(0.62-2.49)$ & 0.542 \\
\hline Between $>16$ and 24 hours & 45.6 & 40.7 & $1.22(0.55-2.68)$ & 0.620 \\
\hline Between $>24$ and 48 hours & 32.1 & 47.4 & $0.52(0.26-1.04)$ & 0.063 \\
\hline
\end{tabular}

on average, pain intensity throughout the observed 48-hour period was at the level that could be characterized as "mild-to-moderate". The relationship between VAS pain scores and the levels of pain intensity ("mild", "moderate" and "severe") specifically in children and adolescents undergoing spondylodesis due to structural scoliosis has not been established. However, a recent cross-sectional analysis of 2794 adults and adolescents with musculoskeletal pain undergoing rehabilitation treatment (14) indicated that scores $\leq 5$ (on a 0-10 scale) would correspond to "mild pain".

The authors also conducted a literature review identifying similar studies: those pertaining to lower back injuries or spinal cord injury indicated cut-offs between "mild" and "moderate" pain at scores in the range between 3-5 (14). Therefore, it is reasonable to assume that both the patients treated using the anterior approach and those treated using the posterior approach in the present samples suffered "mild-to-moderate" pain over the period between 0-6 hours after surgery, and mild pain afterwards. Under such circumstances, the observed difference might not be practically relevant. Still, the data strongly in- dicate a lower analgesic efficiency of the protocol in the posterior approach, which for individual patients might make a relevant difference and suggest that an alternative, more "potent" protocol might be more suitable in this setting. 


\section{References}

1. Yaman O, Dalbayrak S. Idiopathic scoliosis. Turk Neurosurg. 2014;24(5):646-57.

2. Fadzan M, Bettany-Saltikov J. Etiological Theories of Adolescent Idiopathic Scoliosis: Past and Present. Open Orthop J. 2017;11:1466-89.

3. Radl R, Maafe M, Ziegler S. Scoliosis: the bent spine. Orthopade. 2011;40(5):449-62.

4. Altaf F, Gibson A, Dannawi Z, Noordeen H. Adolescent idiopathic scoliosis. BMJ. 2013;346:f2508.

5. Kalichman L, Kendelker L, Bezalel T. Bracing and exercise-based treatment for idiopathic scoliosis. J Bodyw Mov Ther. 2016;20(1):56-64.

6. Wimmer C, Siam AE, Pfandlsteiner T. Operative treatment of scoliosis: Preoperative planning, intraoperative monitoring, and postoperative management. Orthopade. 2015;44(11):859-68.

7. Hibbs RA. An operation for progressive spinal deformities: a preliminary report of three cases from the service of the orthopaedic hospital. 1911. Clin Orthop Relat Res. 2007;460:17-20.

8. King HA, Moe JH, Bradford DS, Winter RB. The selection of fusion levels in thoracic idiopathic scoliosis. J Bone Joint Surg Am. 1983; 65(9):1302-13.
9. Halm H. Ventral and dorsal correcting and stabilizing methods in idiopathic scoliosis. Long-term outcome. Orthopade. 2000;29(6):543-62.

10. Quack V, Rath B, Schenker $H$, Schulze A, El Mansy $Y$, Tingart M, Betsch M. Fusion in adolescent idiopathic scoliosis: Anterior, posterior or combined? One-stage or two-stage? Orthopade. 2015;44(11):879-84.

11. Hudcova J, McNicol E, Quah C, Lau J, Carr DB. Patient controlled opioid analgesia versus conventional opioid analgesia for postoperative pain. Cochrane Database Syst Rev. 2006;(4):CD003348.

12. Pestano CR, Lindley P, Ding L, Danesi H, Jones JB. MetaAnalysis of the Ease of Care from the Nurses' Perspective Comparing Fentanyl Iontophoretic Transdermal System (ITS) Vs Morphine Intravenous Patient-Controlled Analgesia (IV PCA) in Postoperative Pain Management. J Perianesth Nurs. 2017;32(4):329-40.

13. Seki $H$, Ideno $S$, Ishihara $T$, Watanabe $K$, Matsumoto $M$, Morisaki H. Postoperative pain management in patients undergoing posterior spinal fusion for adolescent idiopathic scoliosis: a narrative review. Scoliosis Spinal Disord. 2018;13:17.

14. Boonstra Am, Stewart RE, Koke AJA, Oosterwijk RFA, Swaan JL, Schereurs KMG, Preuper HRS. Cut-off points for mild, moderate, and severe pain on the numeric rating scale for pain in patients with chronic musculoskeletal pain: variability and influence of sex and catastrophizing. Front Psychol 2016;7:1466. 


\section{STANDARDNA MULTIMODALNA POSLIJEOPERACIJSKA ANALGEZIJA MOŽDA NIJE JEDNAKO USPJEŠNA U USPOREDBI PREDNJE I STRAŽNJE SPONDILODEZE}

\section{Sažetak}

Uvod. Kirurško liječenje strukturalnih adolescentnih skolioza prednjim ili stražnjim kirurškim pristupom za posljedicu ima jaku poslijeoperacijsku bol.

Cilj. U usporedbi s prednjim pristupom, smatra se da stražnji pristup ima prednosti u mogućnosti liječenja više skoliotičnih zavoja kralježnice u jednom operativnom aktu. Željeli smo usporediti uspješnost multimodalnog protokola za bol temeljenog na morfiju u prvih 48 sati poslijeoperacijskog tijeka kod pacijenata operiranih prednjim i stražnjim pristupom.

Metode. Ovaj retrospektivni pregled obuhvatio je uzastopne adolescentne pacijente (u dobi od 10 do 21 godine) liječene prednjim $(n=28)$ i stražnjim $(n=30)$ pristupom u jednom bolničkom centru kroz tri godine (2015. - 2017.). Intravenska aplikacija morfija (48 mg / 24 h) provedena je u intervalima od jednog sata, bol je evaluirana primjenom vizualne analogne skale (VAS za bol) u 11 točaka (veći broj = intenzivnija bol) u 12 navrata tijekom prva 24 sata te tri navrata tijekom druga 24 sata. Dodatni analgetici (neopioidni ili slabi opioidni) aplicirani su prema subjektivnim potrebama pacijenata ili procjeni medicinskog osoblja.

Rezultati. Uz korekcije za dob i broj spinalnih segmenata zahvaćenih operacijskim liječenjem, VAS za bol bila je niža kod prednjeg pristupa, ukupno (48 sati) (razlika $=-18 \%, 95 \% \mathrm{Cl}-30$ do $-5 \%$ ) i posebno u periodu od 0 do 3 sata $(-23 \%, 95 \% \mathrm{Cl}-36$ do $-7 \%) \mathrm{i}$ periodu od 4 do 6 sati $(-26 \%$, $95 \% \mathrm{Cl}-40$ do $-10 \%)$ nakon operacijskog zahvata. Stopa dodatno admini- striranih analgetika bila je usporediva tijekom čitavoga promatranog perioda (omjer stopa 1,0).

Zaključak. Promatrani intravenski multimodalni protokol baziran na morfiju pokazao se manje uspješnim u pacijenata operiranih stražnjim pristupom, sugerirajući da dva promatrana kirurška pristupa zahtijevaju različite protokole za isti stupanj analgezije.

Ključne riječi: skolioza, spondilodeza, kontrola boli, analgetici 